\title{
Ethics of limb disposal: dignity and the medical waste stockpiling scandal
}

\author{
Esmée Hanna, ${ }^{\oplus 1}$ Glenn Robert $^{2}$
}

1 Institute of Allied Health Sciences, De Montfort University, Leicester, UK 'Department of Adult Nursing, King's College London, London, UK

\section{Correspondence to} Dr Esmée Hanna, Institute of Allied Health Sciences, De Montfort University, Leicester LE1 9BH, UK :

esmee.hanna@dmu.ac.uk

Received 3 May 2019 Revised 12 June 2019 Accepted 7 July 2019 Published Online First 29 July 2019

\section{Check for updates}

(C) Author(s) (or their employer(s)) 2019. No commercial re-use. See rights and permissions. Published by BMJ.

To cite: Hanna E, Robert G. $J$ Med Ethics

2019;45:575-578.

\section{ABSTRACT}

We draw on the concept of dignity to consider the ethics of the disposal of amputated limbs. The ethics of the management and disposal of human tissue has been subject to greater scrutiny and discussion in recent years, although the disposal of the limbs often remains absent from such discourses. In light of the recent UK controversy regarding failures in the medical waste disposal and the stockpiling of waste (including body parts), the appropriate handling of human tissue has been subject to further scrutiny. Although this scandal has evoked concern regarding procurement and supply chain issues, as well as possible health and safety risks from such a 'stockpile', the dignity of those patients' implicated in this controversy has been less widely discussed. Drawing at Foster's (2014) work, we argue that a dignity framework provides a useful lens to frame consideration of the disposal of limbs after amputation. Such a framework may be difficult to reconcile with the logic of business and the 'biovalue' of the medical waste, but would we argue afford more patient-centred approaches towards disposal. It may also facilitate better practices to help mitigate future stockpiling incidences.

\section{CONTROVERSIES IN MEDICAL WASTE DISPOSAL}

As we have recently highlighted, failures by a waste disposal contractor-Healthcare Environmental Services (HES) - to handle waste effectively and in a timely manner from 50 hospital trusts led to body parts from amputations-and other medical waste-being 'stockpiled'. ${ }^{12}$ The dignity of patients was little discussed during this scandal. Here we highlight broader ethical issues central to these events, and in doing so illuminate wider considerations around the disposal of limbs.

The controversy was brought to light by the Health Service Journal after it was revealed to them that this stockpile had been the subject of a government COBRA meeting chaired by the Secretary of State for Health on 13 September 2018. At this meeting, the government agreed that regulatory action should be taken against HES and that trusts should stop paying them. ${ }^{1}$ At that time, HES had the sole contract for all National Health Service (NHS) hospitals in Scotland and 20\% of the NHS waste disposal market as a whole. ${ }^{1}$ At one of the HES's sites in Normanton, West Yorkshire, 350 tonnes of waste-including anatomical parts such as limbs-were being stored at five times the capacity and licence of the site. The Newcastle HES site was also found to be operating ineffectively with waste types being mixed and inadequately stored. It was found that some body parts had been stored for over 6 months, with some not housed in refrigerated units during this period. ${ }^{3}$ The Environment
Agency inspector stated that in the area used to store anatomical waste at Normanton there was '...such a strong, powerful odour of decaying flesh mixed with a highly intense chemical odour of disinfectant that I was unable to stay in the entrance to the unit for more than a few seconds'. ${ }^{4}$ As a result, the Environment Agency issued a partial shutdown of the Normanton site in early October. Fifteen trusts whose waste was handled at this site (including trusts in Leeds, York, Sheffield and North Lincolnshire) cancelled their contracts with HES. ${ }^{5}$ It was reported that HES collected approximately 590 tonnes of incineration only waste (which includes 'solid' waste, such as body parts) per month, as well as 1900 tonnes of non-hazardous clinical waste, demonstrating the scale of the issue in terms of the numbers of patients potentially implicated as a result of this stockpile.

It later transpired that the firm had been served 13 warning and 2 compliance notices by the Environment Agency since March 2018. ${ }^{3}$ I ndeed, between 2015 and 2017, HES had been warned 43 times for breaching permits ${ }^{3}$ highlighting a broader problem than first thought when the scandal broke in early October 2018. A rival waste management company to HES, SRCL, had brought a legal case against NHS England over the awarding of HES' contract in 2018; they claimed that there was a race to the bottom in the market for waste disposal and-in holding a reverse auction to select a contractorservice quality was not a consideration during the procurement process. ${ }^{6}$ Although they have not entered administration, HES ceased trading in December of 2018. Another company-Mitiewere subsequently contracted by NHS England to provide waste management services to affected trusts, and the government provided specialist containers to house waste during the immediate aftermath of the scandal. There have subsequently been complaints about the service provided by Mitie and additional costs have been of serious concern to trusts. ${ }^{7}$ At the time of writing, the stockpile has not been fully cleared from the former HES site (Carding, personal communication).

The Minister for Health provided a statement to Parliament on the 9 October 2019. In this, he noted that,

\footnotetext{
'...the primary concern was that too much waste was being held in a number of waste storage and treatment sites by a contractor, Healthcare Environment Services (HES). While the waste was stored securely, it was not being processed and disposed of within the correct regulatory timescales. At no point has there been an impact on public health or any delay to the ability of the NHS to carry out operations' (Stephen Barclay, written statement 9 October 2018).
} 
In his statement, Barclay sought to downplay the role of human body parts within the scandal, claiming only $1.1 \%$ of clinical waste was anatomical. Even at conservative estimates, this would equate to approximately 140 tonnes per month and relate to thousands of NHS patients. We know, for example, there are 7000 amputations due to diabetes alone in the UK per year, with a further 4000 due to peripheral arterial disease. ${ }^{8}$ The government was keen to assure parliament that there was enough capacity for incineration in the UK (with 24 incinerators nationally and capacity for handling 2269 tonnes per month) ${ }^{5}$ and that there would be no disruption to NHS services as a result. HES were thus positioned as a 'rogue trader' within this discourse; the scandal was seen as an extreme case rather than a systemic issue.

The government subsequently sought to reassure the public that their health was in no way at risk due to this 'stockpile'. However, they failed to acknowledge to the public or parliament that patients themselves were at the centre of this scandal. ${ }^{2}$ To avoid any future incidents, the government's response was to seek an urgent review of procurement processes. ${ }^{6}$ In doing so the issue of disposal was situated as a procurement failure; specifically, that the contractor had been unable to fulfil adequately the duties for which they were originally contracted. The beliefs, wishes and expectations that patients may have had around the disposal of their body parts were not central to the response. Consequently, the scandal further highlighted how human body parts—-stockpiled in waste management sites—were being treated in an inappropriate manner(). Here, we seek to examine the ethics of disposal practices-specifically in relation to body parts from amputations - asking what then is the 'ethics of parts' in such situations. ${ }^{10}$ In doing so, we explore how Foster's ${ }^{11}$ notion of dignity in relation to body parts might demonstrate how failures of disposal are problematic for all involved.

\section{COMMODIFICATION OF HUMAN BODY PARTS}

Human body parts have increasingly become a source of commodification within contemporary societies. ${ }^{12}$ Discussions of this trend are typically framed in terms of the expansion in the capability of biomedicine to "fragment" ${ }^{13}$ the body into its constituent parts. Components of the body such as organs, blood, cell material or removed limbs have an increasingly independent 'value' outside the sphere of the body from which they originate. Other forms of commodification have also been noted. For example, Klinenberg ${ }^{14}$ argued that in the case of a sharp rise in deaths due to a heatwave in America, the bodies of the victims took on a new commercial value for the media; selling more newspapers was linked directly to these bodies. 'Value' is not therefore always related to reuse of the parts in the traditional sense of recirculation of parts or matter (such as in the cases of organ donation or placenta encapsulation). Although the circulation of the body parts within bioscience and other 'economies' has primarily focused on '(Re)usable' parts, ${ }^{15}$ 'biovalue'16 can also be found within 'waste' products. The framing of the waste stockpiling by HES as a failure in procurement as outlined above, positions medical 'waste' (including limbs) as part of a broader economy and commercial infrastructure, thereby commodifying the waste itself. HES reported profits of $£ 15.4$ million in 2017 with an $18 \%$ growth in their business. ${ }^{6}$ However, limbs such as those involved in the stockpiling scandal derived from patients who may be mourning their loss and may not consider them as 'waste', let alone commercial waste. Yet the human body and its constituents have slowly, through procurement practices and the commercialisation of waste, been introduced into the realm of the market and of property law (although it could be argued that this is contrary to a substratum of human rights, namely that of human dignity).

\section{AMPUTATIONS AND LIMB DISPOSAL}

Undergoing an amputation is often a traumatic experience. Patients may continue to identify the amputated limb as belonging to them, seeing it as both part of me but also mine. ${ }^{17}$ In this sense, the amputated limb is both object and subject, part of the patients' identity but also now a part within its own right, creating tension and sense of loss for patients. It has been suggested that the loss of a limb is of equivalent grief to patients as being widowed ${ }^{18}$; thus, the significance of amputation and the loss of the once attached part should not be understated. Patients with religious beliefs-notably those of Catholic, Jewish and Muslim faiths-have specific preferences around the return of their bodies to the earth; disposal can intersect (and contradict, in the case of incineration) with the broader wishes of such patients. Patients may also express concerns around the dignity afforded to their amputated limbs. Early medical research noted these fears among patients ${ }^{19}$ and similar concerns are evident within more recent medical commentary on the subject. ${ }^{20}$ Giving patients a choice around disposal is a possible means to help navigate the mourning, loss and adaptation to amputation. ${ }^{21}$ Disposal matters to patients, for reasons including their sense of ownership, their religious beliefs about the body or as part of their mourning their altered body and the loss they have experienced. Yet the importance that disposal of limbs may hold for patients is not being respected in practice. ${ }^{2}$ If we adopt Scheper-Hughes's ${ }^{15}$ contention that 'Body parts are, and should remain, private parts, free of outside meddling' (p3), how do we then ethically resolve the 'meddling' of improper disposal and management of limbs within contemporary waste management practices?

\section{DIGNITY IN THE CONTEXT OF LIMB DISPOSAL}

If 'an amputated leg arguably deserves better care than a one-way ticket to the incinerator' (Jansen, p7), ${ }^{21}$ then those limbs that become stockpiled due to poor waste management practices are in receipt of very poor care indeed. The Human Tissue Authority does not provide specific guidance around the disposal of limbs after amputation, although the Human Tissue Act of 2004 details that 'decent disposal' is to be provided for tissue removed from the human body (part $1^{8}$ : p8). The Human Tissue Act was a response to the organ retention scandal at Alder Hey Children's hospital where 800 organs were stockpiled from children after their deaths without consent. ${ }^{12}$ Though the features of the current stockpiling controversy are qualitatively different from events at Alder Hey, patients remain at the heart of both incidents. Although 'dignity has been much maligned' (11, p 45), we would argue it provides a useful lens in this case of disposal practices for limbs just as it did in relation to events at Alder Hey.

The Human Tissue Authority specifies within its guidance that, 'the disposal of human tissue should be managed sensitively and the method of disposal should be appropriate to the nature of the material'. ${ }^{22}$ Although not providing details regarding the means for disposal, The Human Tissue Act takes consent for disposal as being part of the clinical process. This builds on the position of the Nuffield Council on Bioethics report, which rejected that patients 'own' their amputated limbs after the act of amputation and viewed consent for the procedure, that is, amputation, inferring consent for disposal. Such disposal, must 
however, as noted above, be a 'decent disposal' (see Section 4 of Part 3). It is in this context that dignity as an ethical framework can intersect with the disposal and might usefully be extended to all those involved (patients, clinicians and medical waste management staff). Dignity as a primary consideration may also help policy-makers and regulators to plan how practices could best be designed, implemented and monitored in the future.

Foster ${ }^{11}$ explores how dignity can be used as a guiding principle in relation to body parts. Although critiqued for being too 'vague' or non-applicable in all contexts, ${ }^{23}$ dignity offers the potential for moving beyond solely property-based notions of bodies 'in parts', and towards a means by which to examine issues central to limb stockpiling. Foster encapsulates dignity as being connected to human flourishing; dignity should be associated with our being rather than something possessed which can be lost. ${ }^{11} \mathrm{~A}$ body part does not need to be doing anything, to $b e$, and Foster tests his notion of dignity in relation to the misuse of body parts, such as to detail how a human ear being used as an ashtray is not dignified. Similarly, the limb to be disposed of is a body part which is no longer alive but remains an object (and for some patients, still part of their subject).

\section{THE INDIGNITY OF LIMB DISPOSAL IN THE STOCKPILING CASE}

Human dignity is undermined in several ways through the stockpiling of amputated limbs. These relate primarily to the patient, but—as with the 'test cases' in Foster's work—dignity extends to others in the process of managing body parts. First, the mourning of a body part is potentially hindered by its improper management and disposal; the body from which the limb(s) came from may live on and in order for those persons to thrive their bodies need to be treated in a respectful manner. Amputation is akin to the grief of being widowed ${ }^{18}$; many patients report thinking about their limb after it is amputated with many wondering what happened to their limb during its disposal. ${ }^{24}$ For people to thrive, a sense of psychological well-being is needed, but concerns about the disposal of limbs can be a source of distress and anxiety. ${ }^{20} 25$ The amputated limb is still seen by many patients as part of their identity; it is 'their leg', ${ }^{26}$ their sense of self and just as they would expect their 'intact' body to be treated in a dignified manner within a medical encounter, so too is there an expectation of their limb being treated appropriately, despite its amputation from the body.

Second, patients' wishes survive the disposal of the limb. If they entrust a hospital to dispose of their limb - via explicit or implicit consent to their limbs being managed as 'waste'-then it is likely that most patients would not want to think of their limb in a stockpile of body parts in a warehouse. Our own Patient and Public Involvement work on this topic strongly indicates that good care around disposal is seen as key and that disposal should be given greater consideration within the amputation process. Third, clinicians who mediate between a patient and the waste management system - and who assign a limb to that systemlikely believe said waste will be handled in accordance with the guidance and authority of the Human Tissue Act. Finally, any waste management company permitting stockpiling to occur acts in an undignified way; it is dehumanising to employees to work in this environment but also dehumanises those who have seemingly put profit ahead of proper actions in relation to the disposal.

Taken together, such arguments identify contemporary waste management practices as a failure to provide dignified disposal. The appropriate and sensitive handling of limbs as guided by the Human Tissue Authority, and the 'decent disposal' expected by the Human Tissue Act cannot be said to have been met; such practices fail to allow for 'being a human, well' (Foster, p421). ${ }^{23}$ Dignity is useful in this context as it allows the issue of body parts to be considered not from the perspective of property and ownership positions, but from the viewpoint not only of the patient, but also others involved. Using dignity as a guiding principle therefore can also bring positive benefits to the more dignified practice of others, and although patients must be central to these concerns, additional positive benefits to clinicians and those working in waste management are useful to consider. We note recent attempts to address dignified limb disposal being led by communities for their citizens, such as UK's only shared limb burial site in Sheffield, ${ }^{27}$ which was funded by the Muslim community within the city. Such an example highlights what can be achieved where dignity for patients and their 'estranged' limbs is the starting point in the process of disposal.

The framing of disposal through the lens of dignity also allows us to examine the tensions between dignity and 'biovalue' that exist within waste management systems. ${ }^{16}$ The commercial logic of transforming value from medical waste identifies market tendencies-efficiency, cost saving and profit margins-as central values. In contrast, although dignity is something that is valued both morally and ethically, it is also valued through the law, for example, in Article 8 of the European Convention on Human Rights. This Article attends to the right to respect for private and family life, home and correspondence; it is suggested that dignity finds its natural home here, dealing as it does with (among others) matter pertaining to healthcare, end of life and burial. ${ }^{23}$ Where the law values the dignity, the law is the condition 'under which the choice of one can be united with the choice of another in accordance with a universal law of freedom' $(28$, p27). Dignity is however not something that can easily be transformed into value or commodified in some way; aligning dignity and biovalue would potentially place a greater burden on policy-makers in trying to reconcile the logic of industry and commercial medical waste disposal and the dignified disposal of limbs after amputation. ${ }^{23}$ Other means to approach 'proper' management of the disposal of limbs might include recourse to property law perspectives, but-as Goold ${ }^{28}$ has argued — this has been an area of significant discussion and legal challenge. Ideals of ownership in the context of medical waste can also be highly contested. The notion of 'abandonment' within the property proposition in relation to amputated limbs lost through surgery does serve the logic of commercial waste management but fails to keep the patient central to that experience. Such a property law perspective risks overlooking patients feelings and wishes around the disposal.

We would therefore argue that the dignified disposal of parts of human bodies deserves robust consideration and scrutiny of practices for all involved (patients, healthcare professionals and waste management companies) in order that commercial logics-such as the 'race to bottom' that perhaps preceded this most recent scandal-are not the only drivers in our contemporary healthcare systems.

\section{CONCLUDING REMARKS}

There are fundamental lessons for healthcare systems and practices to learn from the stockpiling scandal, not just in relation to procurement practices, but in terms of dignity and an ethical approach to patient care that encompasses the disposal of their amputated limbs. Although medical waste is little discussed or considered, patients and their dignity are inherently connected to the disposal of 'waste'. We should strive to ensure that we 
'treat' waste quickly, appropriately and in a dignified manner which respects the patient. Bringing considerations of dignity to bear on the management of medical waste offers a means of encouraging contractors to both uphold required regulations and adopt a more patient-centred approach with the aim of preventing further stockpiling of 'waste'.

Acknowledgements We would like to thank our colleagues Bart Jansen and Rogier Baart for their helpful discussions and comments which helped us in the early drafting of this paper.

Contributors EH: planned and drafted this article, including conducting the background reading and secondary research. EH and GR: contributed equally to the refinement and writing of this piece.

Funding The authors have not declared a specific grant for this research from any funding agency in the public, commercial or not-for-profit sectors.

Competing interests None declared.

Provenance and peer review Not commissioned; externally peer reviewed.

\section{REFERENCES}

1 Carding N, Lintern S, Clover B, et al. Exclusive: trusts alerted as firm stockpiles clinical waste and body parts. Health Service Journal 2018 https://www.hsj.co.uk/policy-andregulation/exclusive-trusts-alerted-as-firm-stockpiles-clinical-waste-and-body-parts/ 7023511.article (Accessed 12 Apr 2019).

2 Hanna E. Patient dignity must be central to appropriate disposal of body parts. BMJ Opinion 2018 https://blogs.bmj.com/bmj/2018/10/19/esmee-hanna-patient-dignitycentral-appropriate-disposal-body-parts/.

3 Carding N, Scott R. Exclusive: patients' body parts were stored dangerously for six months. Health Service Journal 2019 https://www.hs..co.uk/quality-and-performance/ exclusive-patients-body-parts-were-stored-dangerously-for-six-months/7024171. article (Accessed 12 Apr 2019).

4 Matthews- King A. NHS Patient body parts stored unrefrigerated for six months at NHS waste firm, inspection report reveals. The Independent $2019 \mathrm{https}: / / \mathrm{www}$. independent.co.uk/news/health/body-parts-scandal-nhs-waste-human-remains-toxichealthcare-environment-services-hsj-a8730481.html (Accessed 12 Apr 2019).

5 Barclay S. The Minister for health. Clinical waste update. Hansard. 2018.

6 Clover B. Government reviewing procurement process after 'human body parts' scandal. Health Service Journal 2018 https://www.hsj.co.uk/policy-and-regulation/ government-reviewing-procurement-process-after-human-body-parts-scandal/ 7023513.article (Accessed 12 Apr 2019).

7 Carding N. Trusts bemoan cost pressures from clinical waste switch. Health Service Journal 2019 https://www.hsj.co.uk/finance-and-efficiency/trusts-bemoan- cost-pressures-from-clinical-waste-switch/7024526.article (Accessed 12 Apr 2019).

8 Ahmad N, Thomas GN, Gill P, et al. Lower limb amputation in England: prevalence, regional variation and relationship with revascularisation, deprivation and risk factors. A retrospective review of hospital data. J R Soc Med 2014;107:483-9.

9 Quinn B. NHS supplier that kept body parts faces criminal investigation. The Guardian $2018 \mathrm{https} / / / \mathrm{www}$.theguardian.com/society/2018/oct/05/criminal-investigation-afternhs-supplier-retained-body-parts (Accessed 12 Apr 2019).

10 Cohen L. Where it hurts: Indian material for an ethics of organ transplantation. Daedalus 1999;128:135-65.

11 Foster C. Dignity and the use of body parts. J Med Ethics 2014;40:44-7.

12 Seale C, Cavers D, Dixon-Woods M. Commodification of body parts: by medicine or by media? Body Soc 2006;12:25-42.

13 Sharp LA. The commodification of the body and its parts. Annu Rev Anthropol 2000;29:287-328.

14 Klinenberg E. Bodies That Don't Matter: death and dereliction in Chicago. Body Soc 2001;7(2-3):121-36.

15 Scheper-Hughes N. Bodies for sale - whole or in parts. Body Soc 2001;7(2-3):1-8.

16 Waldby C. Stem cells, tissue cultures and the production of biovalue. Health 2002;6:305-23.

17 Crawford CS. 'You don't need a body to feel a body': phantom limb syndrome and corporeal transgression. Sociol Health IIIn 2013;35:434-48.

18 Maguire P, Parkes CM. Coping with loss: surgery and loss of body parts. BMJ 1998:316:1086-8.

19 Blood AM. Psychotherapy of phantom limb pain in two patients. Psychiatr Q 1956;30(1):114-22.

20 Marlow S. Can I cremate my own leg? BMJ 2008;336:774.

21 Jansen B, Baart RI. I am my leg, do I have my leg, where is my leg? Towards radical post-amputative self-determination. Working paper. Forthcoming.

22 Human Tissue Authority. Code of Practice- Guide A: Guiding principles and the fundamental principle of consent Para 13d [Online]. 2014 https://www.hta.gov.uk/ sites/default/files/HTA\%20Code\%20A_1.pdf.

23 Foster C. Dignity and the ownership and use of body parts. Camb Q Healthc Ethics 2014;:23:417-30

24 Gallagher P, MacLachlan M. Positive meaning in amputation and thoughts about the amputated limb. Prosthet Orthot Int 2000;24:196-204.

25 Rudd P. Starting out - a request to cremate an amputated limb raised issue of spiritual care. Nurs Stand 2014;28:28.

26 Sobchack V. Living a 'Phantom Limb': on the phenomenology of bodily integrity. Body Soc 2010;16:51-67.

27 Hanna E. "What Do you want to do with the leg?" a critical narrative review of the understandings and implications of disposal in the context of limb amputations. Sage Open 2019;9:215824401985995.

28 Goold I. Abandonment of human tissue. In: Persons, parts and property: how should we regulate human tissue in the 21st Century. London: Bloomsbury Publishing, 2014:125-55.

29 Kant I. The Metaphysics of Morals. Cambridge, UK: Cambridge University Press, 2017. 